\title{
DISSENSOS NO CONSENSO: A DEMOCRATIZAÇÃO DA ESCOLA PÚBLICA EM MATO GROSSO*
}

\author{
Gesuína de FÁtima Elias Leclerc ${ }^{* *}$
}

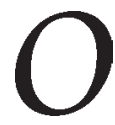

livro de Odorico Ferreira Cardoso Neto é o resultado da sistematização de uma experiência da maior relevância na década de 1990, no estado de Mato Grosso, a partir de suas pesquisas no curso de mestrado em educação da UFMT, sob orientação da professora doutora Artemis Torres. O autor retoma o processo de proposição do Sistema Único de Ensino, em seu marco institucional principal: a realização da Conferência Estadual de Educação, ocorrida em novembro de 1996. Essa proposiçāo faz convergir os esforços de militância do Sindicato dos Trabalhadores no Ensino Público de Mato Grosso (SINTEP-MT) e a plataforma democratizante do plano de governo das forças políticas coligadas na Frente Cidadania e Desenvolvimento (1994-1998), numa mesa de negociação ampliada, envolvendo a representação dos usuários da escola pública, para definir os termos de reordenamento do ensino. Foram mais de 10 mil participantes e 490 emendas, somando o trabalho de base em 90 dos 119 municípios mato-grossenses, como expressão de um processo desejado, para uma democracia pensada "de baixo para cima". $\mathrm{O}$ autor faz o detalhamento da participação dos municípios. Fiel ao processo vitorioso no marco institucional, desenvolve uma idéia de sistema como um conjunto de elementos materiais e ideais, chegando à idéia do Sistema Único de Ensino como "a possibilidade real de se reorganizar o sistema educacional público, eliminando as redes estadual e municipal, por meio de uma gestão única e cooperada entre estado, municípios e as comunidades escolares" (p. 64). O governo não reconheceu o resultado da conferência, embora a tenha promovido e financiado.

\footnotetext{
* Resenha do livro Dissensos no consenso: a democratização da escola pública em Mato Grosso, de Odorico Ferreira Cardoso Neto (Cuiabá: Editora da UfMT, 2004).

** Doutoranda no Programa de Pós-Graduação em Educação da Universidade Federal da Paraíba (UFPB) e bolsista da CAPES. E-mail: aleclerc@openline.com.br
} 
$\mathrm{Na}$ releitura desse processo salta aos olhos a relação sindicato/governo e sociedade como mediadora da noção de democracia. A democracia está conectada ao conceito de "hegemonia" na perspectiva gramsciana, por estar vinculada à relação entre os grupos dirigentes e os grupos dirigidos. Conectada também à legislação que expressa uma parte significativa dos conflitos negociados, com um limite preciso: requer a mobilização permanente para a sua viabilização. Assim, reconhecer o processo democrático e produzir processos democratizadores envolve um movimento duplo, de construção de espaços de cidadania e de institucionalização normativa, que pode resultar em qualidade da educação. É preciso evidenciar a cultura política, persistente, do autoritarismo nos sistemas de ensino. Diante dessa cultura política, o termo "burocracia", por exemplo, não está relacionado ao sentido weberiano atribuído a um aparelhamento racional-legal, mas compreende a apropriação de um cargo que tem valor em si mesmo, sem nenhuma esfera pública, sem nenhum mecanismo de controle social. Isso ainda se repete mesmo com a eleição de diretores e com a composição de conselhos deliberativos escolares; então o processo pressupõe um tipo especial de projeto político-pedagógico. A gestão democrática não é uma forma de gerência neutra e desvinculada da formação continuada dos atores envolvidos. Temos pouquíssimo registro da formação dos membros dos conselhos deliberativos. O autor estimula uma leitura da democracia como um investimento teimoso na construção da cultura da participação para exterminar o clientelismo, o assistencialismo e a corrupção.

$\mathrm{O}$ (a) leitor(a) poderá acompanhar o testemunho e as reflexões dos sindicalistas, como o atual presidente do SINTEP-MT, Júlio Cezar Martins Viana, descrevendo os passos lentos para uma nova realidade institucional, na qual se possa falar em interlocução entre sindicato e governo. $\mathrm{O}$ magistério mato-grossense aprendeu a falar em "democracia" saindo da experiência de um governo que gesticulava dando "banana" para o povo, que exibia ostensivamente a caneta para dizer que detinha o poder para demitir e mandar e que chamava as professoras de "mulheres mal-amadas". Mas o autor também busca a opinião dos antigos membros dos governos, ex-secretários de Educação que se posicionam com relação à gestão democrática. Não se trata de uma luta entre mocinhos e bandidos. $\mathrm{O}$ ponto de convergência e de consenso entre o que pensam sindicalistas e ex-secretários de Educação está na "antevisão de que o processo de democratização da educação é irreversível, irrenunciável e inacabável” (p. 6). 
O revezamento entre os depoimentos dos sindicalistas e dos ex-secretários de Educação tem como pano de fundo a luta para eliminar o clientelismo, para normatizar planos de carreira para o magistério e para proporcionar a formação continuada aos profissionais da educação em nome da qualidade. Algumas das interfaces da luta para que os recursos públicos para a educação sejam gastos exclusivamente no ensino público, e de modo que haja continuidade nas políticas públicas educacionais. Quanto aos recursos públicos, o tema do sistema único de ensino traz à tona novas categorias para o financiamento da educação, especialmente a automatização dos recursos constitucionalmente destinados à educação, a descentralização e a autonomia, num contexto de ajuste fiscal. As formulações sobre automatização de recursos, descentralização e autonomia estão amarradas num feixe de contradições, de conflitos, mas o autor não joga o bebê com a água do banho. Ele procura situar essas formulações no quadro de um sistema político democrático, buscando uma leitura das virtudes de uma outra descentralização e de uma outra autonomia. A descontinuidade das políticas educacionais num mesmo mandato também é tratada, visto que a Secretaria de Estado da Educação de Mato Grosso tem como exemplo contundente o fato de que, entre 1986 e 1990 (período de 5 anos), passaram pelo órgão sete secretários e, entre 1990 e 2002 (período de 12 anos), passaram, comparativamente, apenas seis.

Outro depoimento importante é o de Carlos Abicalil, presidente do SINTEP-MT na época da Conferência, atualmente deputado federal eleito pelo Partido dos Trabalhadores (presidente da Comissão de Educação da Câmara dos Deputados), lembrando o processo de desqualificação da gestão democrática pela enxurrada de Ação Direta de Inconstitucionalidade (ADINS) no final da década de 1980. Naquela época, a lei que regulamentou a gestão democrática em MT foi uma iniciativa da Assembléia Legislativa e deveria ter sido de iniciativa do Executivo, por isso havia, na lei, o que se chama juridicamente de "vício de origem". O Supremo Tribunal Federal deferiu todas as cautelares para suspender disposições em que houvesse participação popular nos atos de investidura de cargos e funções de direção escolar.

$\mathrm{O}$ autor estabelece uma interlocução direta com os estudos da gestão democrática com base no Banco de Dados sobre Movimentos Sociais e Educação daquela universidade. A partir de 1987, a gestão democrática em Mato Grosso apresenta em suas características a adoção de eleição 
de diretores, a instalação de conselhos deliberativos nos quais têm assento - com voz e voto - representantes de todos os segmentos da comunidade escolar, a preconização da autonomia financeira das escolas. A partir da leitura tomamos conhecimento do mapa cronológico sobre a Gestão Democrática nas Escolas Públicas de Mato Grosso. Aprendemos a ver a gestão democrática em seu movimento, a partir de uma ordem cronológica, representada por três conjuntos específicos de caracterizações: a) os acontecimentos, como mobilizações sindicais (greves, panfletagens, denúncias); as ações inovadoras ocorridas no interior de escolas; as ocorrências conjunturais que possam ter tido repercussão sobre a gestão democrática etc.; b) os eventos promovidos por entidades governamentais, acadêmicas e sindicais (simpósios, reuniôes, mesas-redondas, encontros, congressos etc.); c) a legislação (leis municipais, estaduais, federal, normas, decretos etc.).

Entre o que se pode apontar como uma nova característica da gestão democrática está a proposição da fundação pública, na esteira da proposição do Sistema Único de Ensino. Em sua interlocução o autor enfatiza os problemas da nova dinâmica de gestão. Essa fundação deveria gerir todos os recursos da educação em nível de estado e de municípios. O novo desenho da política pública e de oferta pública rompe com a prática concorrencial entre estado e municípios: o estado, proprietário de uma rede e de um corpo funcional, e os municípios, que são proprietários de outra rede e de outro corpo funcional. $\mathrm{O}$ modelo representa uma ameaça, do ponto de vista da lógica tradicional de governo, que passaria a ter uma instância maior que a soma de seus secretários, já que a fundação seria maior que a soma de qualquer secretaria. O grau de autonomia conferido à fundação também escapa ao controle individual dos secretários municipais e do secretário estadual de Educação. O caráter supragovernamental supera o mandato de um governo, já que as eleições não coincidem. O patrimônio coletivo do maior serviço público ofertado seria superior ao de cada um dos municípios. Mas as relações sindicais também se apresentam como problemáticas. E o protagonismo dos usuários da escola pública? Aqui se encontra o limite, que não é o da análise, mas é o da prática sindical, vinculada à representação política também tradicional e ao corporativismo.

$\mathrm{O}$ autor, que também é sindicalista na subsede do SINTEP-MT, em Barra do Garças, na divisa com o estado de Goiás, prossegue seus estudos promissores, no doutorado em educação, na Universidade Federal de Goiás. 